\title{
Tempe sebagai Pengganti Hormon Estrogen pada Reseptor Estrogen $\alpha$ dengan Metode Autodock Vina
}

\author{
Budi Mulyati \\ Jurusan Teknik Industri, Fak. Teknik, Universitas Nurtanio, Jl. Pajajaran No. 219 Bandung \\ b.mulyati@yahoo.com
}

Received: 14/04/2018; Revised: 13/05/2018; Accepted: 13/05/2018

\begin{abstract}
Abstrak
Reseptor Estrogen (RE) $\alpha$ akan berinteraksi dengan estrogen dalam tubuh manusia. Bila kadar Estrogen berkurang akan menyebabkan menopause. Isoflavon merupakan fitoestrogen yang dapat terikat pada kedua jenis estrogen reseptor.Tempe merupakan makanan yang mengandung isoflavon yaitu faktor II (6,7,4-trihidroksi isoflavon). Isoflavon bermanfaat antara lain untuk mencegah penyakit tulang, menurunkan kolesterol jahat, dan mencegah kanker. RE $\alpha$ merupakan target penting dalam dunia pengobatan untuk mencari hormon pengganti pada wanita menopause dan obat kemoterapi melawan kanker. Tujuan dari penelitian ini adalah menentukan urutan ligan yang berinteraksi lebih kuat terhadap RE $\alpha$ serta menentukan gugus fungsi yang berperan aktif dan jenis interaksi yang terjadi antara ligan dan reseptor. Penelitian diawali dengan optimasi struktur RE $\alpha$ (PDB kode 2OUZ), kemudian disimulasikan docking dengan ligan menggunakan autodock Vina, dan ditentukan energi afinitasnya. Ligan yang digunakan pada penelitian ini adalah faktor II, daidzein, genistein, glisitein dan biochanin A dengan estrogen sebagai pembanding. Hasil penelitian ini menunjukkan energi afinitas RE $\alpha$ berturut-turut adalah -6,3 kkal/mol; -6,2 kkal/mol; -6,1 kkal $/ \mathrm{mol} ;-5,9 \mathrm{kkal} / \mathrm{mol}$; dan $-5,7$ $\mathrm{kkal} / \mathrm{mol}$.
\end{abstract}

Kata Kunci: Reseptor Estrogen $\alpha$, Isoflavon, Autodock Vina, Faktor II, Genestein

\begin{abstract}
Estrogen receptor (RE) $\alpha$ will interact with estrogen in the human body. When estrogen levels decrease will cause menopause. Isoflavones are phytoestrogens that can bind to both types of estrogen receptors. Tempe is a food containing isoflavone that is factor II (6,7,4-trihydroxy isoflavones). Isoflavones are useful, among others, to prevent bone disease, lower bad cholesterol, and prevent cancer. RE $\alpha$ is an important target in the world of treatment for seeking hormone replacement in menopausal women and chemotherapy drugs against cancer. The purpose of this study is to determine the order of ligands that interact more strongly against the RE $\alpha$ and determine the functional groups that play an active role and the type of interaction that occurs between the ligand and receptor. The research begins with optimization of structure RE $\alpha$ (GDP code 2OUZ), then simulated docking with ligand using autodock Vina, and determined its affinity energy. The ligands used in this study were factor II, daidzein, genistein, glycinein and biochanin A with estrogen as a comparison. The results of this study show that the energy affinity of RE $\alpha$ is $-6,3 \mathrm{kcal} / \mathrm{mol} ;-6.2 \mathrm{kcal} / \mathrm{mol} ;-6.1 \mathrm{kcal} / \mathrm{mol} ;-5.9$ $\mathrm{kcal} / \mathrm{mol}$; and $-5.7 \mathrm{kcal} / \mathrm{mol}$.
\end{abstract}

Keywords: Estrogen Receptor $\alpha$, Isoflavones, Autodock Vina, Factor II, Genestein

\section{PENDAHULUAN}

Tempe adalah makanan yang dibuat dari fermentasi biji kedelai atau beberapa bahan lain yang menggunakan kapang rhizopus, seperti Rhizopus oligosporus, $R h$. oryzae, Rh. stolonifer (kapang roti), atau
Rh. arrhizus. Sediaan fermentasi ini secara umum dikenal sebagai "ragi tempe". Kapang yang tumbuh pada kedelai menghidrolisis senyawa-senyawa kompleks menjadi senyawa sederhana yang mudah dicerna oleh manusia. Tempe 
kaya akan serat pangan, kalsium, vitamin B dan zat besi. Berbagai macam kandungan dalam tempe mempunyai nilai obat, seperti antibiotika untuk menyembuhkan infeksi dan antioksidan pencegah penyakit degeneratif. Secara umum, tempe berwarna putih karena pertumbuhan miselia kapang yang merekatkan biji-biji kedelai sehingga terbentuk tekstur yang memadat. Degradasi komponen-komponen kedelai pada fermentasi membuat tempe memiliki rasa dan aroma khas. Tempe banyak dikonsumsi di Indonesia, tetapi sekarang telah mendunia. Kaum vegetarian di seluruh dunia banyak yang telah menggunakan tempe sebagai pengganti daging. Akibatnya sekarang tempe diproduksi di banyak tempat di dunia, tidak hanya di Indonesia.

Hormon adalah senyawa-senyawa kimia alami dan dikeluarkan oleh kelenjar endokrin ke dalam sirkulasi darah. Salah satu contoh hormon pada manusia adalah estrogen. Estrogen mempengaruhi pertumbuhan, merangsang perkembangan ciri kelamin sekunder wanita dan berfungsi pada berbagai macam target di jaringan, termasuk jaringan sistem reproduktif pria dan wanita seperti payudara, uterus, ovarium, testis serta prostat. Estrogen juga berperan penting dalam pemeliharaan tulang dan sistem kardiovaskular dimana estrogen mempunyai efek kardioprotektif tertentu (Clark et al., 1992).

Reseptor estrogen merupakan salah satu anggota reseptor inti yang memperantarai aksi hormon estrogen didalam tubuh. Estrogen bekerja meregulasi pertumbuhan dan diferensiasi sel-sel sistem reproduksi baik pada wanita dan pria. Dapat juga meningkatkan kadar kolesterol HDL dan menurunkan LDL, sehingga berpotensi mengurangi resiko penyakit kardiovaskuler. Estrogen berperan penting pada perkembangan otak, penyakit autoimun, metabolisme tulang dan pada sisi lain, estrogen dapat memicu pertumbuhan, proliferasi serta metastase kanker payudara (Prawiroharsono, 2001).

Reseptor estrogen terdiri dari 2 subtipe yaitu, reseptor estrogen $\alpha(\operatorname{RE} \alpha)$ dan reseptor estrogen $\beta(\mathrm{RE} \beta)$. Kedua reseptor ini dibentuk oleh rantai tunggal polipeptida dengan 565 asam amino untuk RE $\alpha$ dan 530 asam amino pada RE $\beta$.

Proses pengikatan hormon pada reseptor estrogen di membran sel, dan berikatan dalam bentuk dimer. Setelah hormon berikatan dengan reseptornya, reseptor berpindah ke inti sel kemudian berikatan dengan ERE (estrogen response element) selanjutnya kompleks tersebut akan berikatan dengan koaktivator sehingga faktor transkripsi menjadi aktif yang dapat mengubah ekspresi gen. Kemudian regulasi transkripsi gen akan menghasilkan suatu protein spesefik yang terlibat dalam fungsi biologis tertentu.

Isoflavon adalah sejenis fitonutrien, yang kaya dalam kacang kedelai dan produk kacang kedelai itu sendiri. Isoflavon terdiri dari empat jenis, yaitu daidzein, genestein, glisitein dan faktor II. Struktur dari isoflavon sama dengan struktur kimia dari estrogen. Estrogen itu sendiri memiliki peran yang sangat penting dan aktif didalam proses penyembuhan penyakit yang disebabkan oleh hormon. Menurut Allred et al (2004) bangsa Asia, khususnya Jepang, memiliki resiko yang lebih rendah untuk terserang penyakit kanker payudara serta gejala menopause, dibanding dengan bangsa Eropa dan sekitarnya. Ini disebabkan oleh banyaknya konsumsi Kacang kedelai di Kalangan Asia. Isoflavon dapat mengurangi kadar kolesterol, yang dapat mengakibatkan 
atherosclerosis dan penyempitan pembuluh darah. Dengan tujuan untuk mengurangi resiko serangan jantung dan stroke.

Pada kacang kedelai banyak mengandung genestein, daidzein dan glisitein (Kuiper \& George, 1998). Pada tahun 1964, Gyorgy $d k k$ menemukan isoflavon yang diisolasi dari tempe tradisional yaitu faktor II (6,7,4'trihidroksiisoflavon).

Menurut penelitian Kuiper \& George (1998) fitoestrogen meliputi genistein, coumestrol dan zearalenone menstimulasi aktivitas transkripsi kedua tipe estrogen reseptor pada konsentrasi 1-10 nM. Peringkat potensi estrogenik fitoestrogen terhadap reseptor estrogen $\alpha$ adalah sebagai berikut: estradiol $>>$ zearalenone $=$ coumestrol > genistein > daidzein > apigenin $=$ phloretin $>$ biochanin $\mathrm{A}=$ kaempferol $=$ naringenin $>$ formononetin $=$ ipriflavone $=$ quercetin $=$ chrysin .

Autodock Vina adalah sebuah program open source untuk melakukan docking molekul. Program ini didesain dan diterapkan oleh Dr. Oleg Trott di Molecular Graphics Lab, Scripps Research Institute. Proses docking melibatkan dua langkah dasar, yaitu prediksi konformasi ligan serta posisi dan orientasi dalam sisi-sisi tersebut serta penilaian afinitas ikatan. Dalam menjalankan Autodock Vina, tidak membutuhkan pengetahuan secara detail, yang dibutuhkan adalah struktur molekulmolekul yang didocking dan spesifikasi dalam mencari sisi pengikatan (Trott, et al., 2010)

\section{METODE PENELITIAN}

Perangkat Lunak yang digunakan dalam penelitian ini adalah ACD/Chemsketch (Advanced Chemistry
Development/Chemsketch), Avogadro, NAMD (Nanoscale Molecular Dynamics), VMD (Visual Molecular Dynamics, Autodock Vina dan Ligplus. ACD/Chemsketch ini digunakan untuk membuat struktur dua dimensi seluruh ligan. Avogadro digunakan untuk visualisasi tiga dimensi ligan dan reseptor. Sedangkan VMD digunakan untuk visualisasi dan preparasi input yang akan digunakan untuk simulasi pada NAMD. NAMD digunakan untuk optimasi struktur protein. Autodock Vina digunakan untuk simulasi docking Reseptor Estrogen $\alpha$ dengan seluruh ligan dengan estrogen sebagai pembanding. Ligplus digunakan untuk visualisasi hasil dari Autodock Vina, sehingga diketahui ikatan antara protein dengan ligan.

\section{Optimasi Struktur Ligan dan Reseptor Estrogen $\alpha$}

Ligan yang digunakan pada penelitian ini sebanyak enam buah yaitu estrogen, genistein, daidzein, glisitein, biochanin A dan faktor II. Struktur ligan digambar menggunakan ACD / Chemsketch kemudian dibuat tampilan tiga dimensi. Input dibuat menggunakan Avogadro untuk selanjutnya dilakukan simulasi optimasi geometri menggunakan Gaussian-09. Optimasi geometri di atur pada temperatur $310 \mathrm{~K}$ dengan basis 6-31 $\mathrm{G}$ (d) dan teori B3LYP.

\section{Simulasi Docking Reseptor Estrogen $\alpha-$ Ligan dan Penentuan Residu Aktif}

Program Autodock Vina digunakan untuk menggabungkan setiap ligan ke RE $\alpha$. Autodock dapat menggabungkan molekul ligan ke molekul protein globular yang rigid berdasarkan algoritma Lamarkian genetic. Model ini mengkombinasikan kecepatan evaluasi 
energi menggunakan prekalkulasi kisi (grid) energi afinitas atomik setiap tipe atom dalam molekul reseptor dengan variasi algoritma pencarian untuk menemukan posisi pengikatan yang sesuai untuk ligan dimana pada penelitian ini digunakan genetic algorithm (GA).

Model estrogen reseptor digunakan sebagai molekul target. Program Autodock Vina 4.0 digunakan untuk menghitung muatan parsial atom dalam molekul target. Kisi kubus (grid box) (18 x 18 x 18) dari interaksi karbon, hidrogen dan oksigen. Dilakukan penambahan hidrogen polar pada RE a menggunakan AutoDock Vina. Proses docking RE $\alpha$ - ligan juga dilakukan menggunakan AutoDock Vina. $\mathrm{RE} \alpha$ yang digunakan adalah RE $\alpha$ dalam bentuk kristalnya sebelum dioptimasi dan RE $\alpha$ dalam bentuk solvasi setelah optimasi. Hasil docking dianalisis menggunakan Pymol. Untuk menentukan residu asam amino yang aktif yang berikatan langsung dengan ligan maka digunakan software Ligplus dengan memasukkan data PDB hasil dari autodock Vina.

\section{HASIL DAN PEMBAHASAN \\ Optimasi Struktur Ligan}

Komputasi kimia dapat menjelaskan dengan teliti sifat dan parameter yang ada dalam sistem kimia. Beberapa diantaranya yaitu penentuan struktur/geometri, frekuensi vibrasi dan spektra berbagai molekul. Tahap awal dari studi komputasi adalah menentukan optimasi geometri. Optimasi geometri bertujuan untuk mendapatkan struktur molekul tiga dimensi dengan energi minimum (keadaan paling stabil). Penentuan optimasi geometri molekul diawali dengan perkiraan awal struktur yang dinyatakan dalam Z-matrik.
Ligan adalah senyawa organik atau anorganik yang berperan dalam interaksi pada domain pengikatan protein dan dapat mempengaruhi aktivitas pada protein tersebut. Ligan dapat berupa substrat, regulator, inhibitor, kofaktor, maupun efektor lain. Dalam penelitian ini, ligan berupa senyawa organik yang berinteraksi dengan sisi aktif protein sebagai molekul pembawa pesan dalam mengaktifkan reseptor untuk melakukan tahap transkripsi. Ligan ini dioptimasi agar didapat energi elektronik seminimal mungkin. Perhitungan ini dilakukan dengan pendekatan DFT (Density Functional Theory) yaitu pendekatan untuk menghitung atau menentukan geometri struktur optimal pada molekul dengan banyak atom secara Quantum Mechanics (QM). Perhitungan ini juga dilakukan dengan pendekatan Born-Oppenheimer yaitu inti atom dianggap diam pada saat meninjau gerak elektron. Sehingga energi elektronik yang dihitung merupakan penjumlahan dari energi potensial elektron dan energi kinetik elektron. Ketika didapat geometri molekul berada pada posisi jarak dan sudut yang paling stabil. Molekul ini merupakan bentuk yang paling optimal pada simulasi yang menyerupai sistem yang sebenarnya. Pada penelitian ini seluruh ligan fitoestrogen dan estrogen dioptimasi menggunakan Gaussian-09.

Struktur protein RE $\alpha$ diambil dari Bank Data Protein dengan kode 2 OUZ.

RE $\alpha$ ini merupakan struktur kristal berupa monomer dengan satu rantai. RE $\alpha$ yang terikat kompleks dengan lasofixene. Namun selanjutnya dalam penelitian lasofixene dihilangkan keberadaannya. Struktur RE $\alpha$ sesudah dioptimasi dapat dilihat pada Gambar 1. 


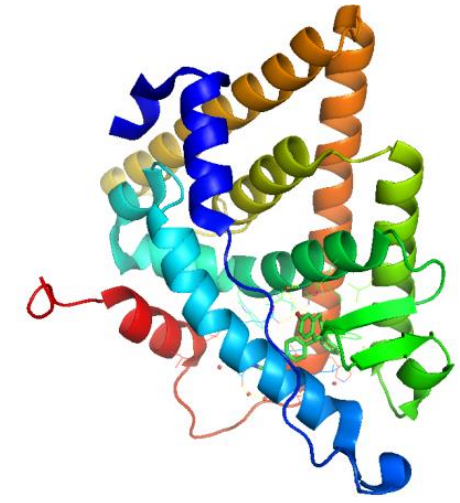

Gambar 1. Reseptor Estrogen $\alpha$ (2OUZ) dari Protein Data Bank (PDB)

Proses Docking dilakukan pada RE $\alpha$ yang sudah dioptimasi dengan ligan yang sudah dioptimasi pula. Pada proses docking, protein reseptor diasumsikan sebagai molekul yang kaku sedangkan ligan diasumsikan sebagi molekul yang memiliki beberapa derajat kebebasan, terutama dalam sudut torsional, karena beberapa parameter lainnya seperti panjang ikatan dan sudut ikatan memiliki nilai konstan untuk konformasi molekul yang berbeda. Oleh karena itu, hasil yang diperoleh setelah tahap docking adalah berbagai energi afinitas interaksi ligan yang dapat terikat pada domain pengikatan ligan RE $\alpha$ (Tabel 1).

Tabel 1. Energi Afinitas Ligan terhadap RE $\alpha$ Hasil docking Autodock Vina

\begin{tabular}{cc}
\hline Nama Ligan & $\begin{array}{c}\text { Energi Afinitas } \\
\text { (Kkal/mol) }\end{array}$ \\
\hline Estrogen & $-6,7$ \\
Faktor 2 & $-6,3$ \\
Daidzein & $-6,2$ \\
Genistein & $-6,1$ \\
Glisitein & $-5,9$ \\
Biochanin A & $-5,7$ \\
\hline
\end{tabular}

Bila dianggap interaksi pembentukan kompleks estrogen dengan RE $\alpha$ yang sudah dioptimasi dalam kondisi berair adalah $100 \%$ maka dapat dilihat persentasi interaksi pembentukan reseptor estrogen $\alpha$ dapat dilihat pada Tabel 2 di bawah ini:

Tabel 2. Perbandingan Persentase Estrogenik dari Isoflavon terhadap Estrogen berdasarkan Binding Energi pada Reseptor Estrogen $\alpha$

\begin{tabular}{cc}
\hline Nama Ligan & Persentasi Interaksi \\
\hline Estrogen & $100 \%$ \\
Faktor II * & $94,52 \%$ \\
Daidzein & $92,53 \%$ \\
Genistein & $91,04 \%$ \\
Glisitein & $88,06 \%$ \\
Biochanin A & $85,07 \%$
\end{tabular}

Keterangan: Untuk ligan yang bertanda* belum ada data eksperimen.

Pada uji transaktivasi secara eksperimen oleh Kuiper, et al (1998) estrogen dan berbagai fitoestrogen dicampurkan ke dalam larutan protein ER $\alpha$, kemudian dilihat inhibisi fitoestrogen tersebut dalam interaksinya terhadap ER $\alpha$. Urutan potensi estrogenik fitoestrogen adalah sebagai berikut: Estradiol $\gg$ zearalenone $=$ coumestrol $>$ genistein $>$ daidzein $>$ apigenin $=$ phloretin $>$ biochanin $\mathrm{A}=$ kaempferol = naringenin > formononetin $=$ ipriflavone $=$ quercetin $=$ chrysin. Sedangkan berdasarkan komputasi urutan potensi estrogenik adalah sebagai berikut : estrogen $>$ faktor $2>$ daidzein > genestein > glisitein> biochanin A. Dari urutan potensi estrogenik yang tidak sama menunjukkan bahwa hasil pemodelan struktur reseptorligan secara komputasi tidak sejalan dengan hasil eksperimen yang dilakukan oleh Kuiper \& George, tapi perbedaannya hanya terletak pada urutan daidzein dan genestein, hal ini dikarenakan adanya gugus $\mathrm{OH}$ yang lebih elektronegatif pada gugus aromatik pada ligan daidzein menyebabkan adanya ikatan hidrogen 
antara ligan dengan reseptor estrogen lebih stabil, dan menyebabkan energi afinitas antara daidzein dan reseptor estrogen menjadi rendah. Walaupun terdapat perbedaan urutan potensi estrogenik antara daidzein dan genestein, namun perbedaannya hanya $1,49 \%$, sehingga perbedaannya tidak terlalu signifikan.

Dari penelitian dapat diambil kesimpulan bahwa dibandingkan dengan isoflavon lain, faktor II memiliki afinitas yang paling tinggi hal ini dikarenakan struktur faktor II mempunyai tiga gugus hidroksil pada posisi C-6, C-7 dan C-4 sehingga probabilitas untuk berinteraksi secara ikatan hidrogen tinggi. Ikatan hidrogen penting dalam pengikatan ligan dan reseptor. Struktur dan orientasi docking dari interaksi secara ikatan hidrogen dari faktor II menyebabkan banyak terbentuknya ikatan hidrogen antara faktor II dan reseptor estrogen.

\section{Gugus fungsi yang berperan pada Reseptor Estrogen $\alpha$}

Dari tabel dapat diketahui bahwa energi afinitas estrogen yang paling rendah dibandingkan ligan lain. Hal ini disebabkan karena estrogen mempunyai gugus fenol pada posisi C-3 dalam cincin aromatik $\mathrm{A}$, inti hidrokarbon yang relatif kaku dan gugus fungsi alkohol pada posisi C-17. Hidroksil dari C-3 berfungsi sebagai donor ikatan hidrogen dan C-17 hidroksi berfungsi sebagai akseptor ikatan hidrogen.

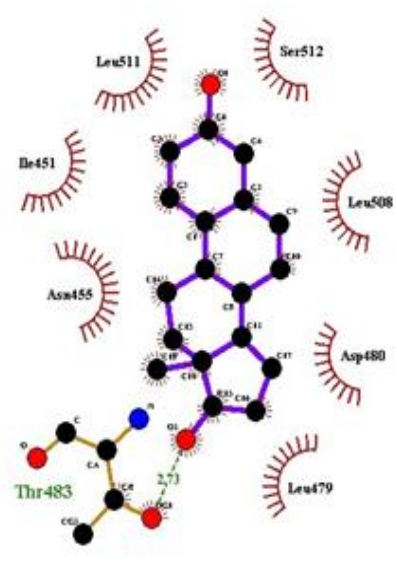

Gambar 2. Hasil ligplot Interaksi RE $\alpha$ dengan Estrogen

Estrogen adalah ligan alami RE $\alpha$. Estrogen yang terikat dengan RE $\alpha$ memiliki energi afinitas paling negatif yaitu sebesar $-6,7 \mathrm{kkal} / \mathrm{mol}$. Interaksi kuat yang terbentuk antara ligan dengan asam amino pada protein berjarak antara 3,0 sampai 5,0 ̊. Jika interaksi antara ligan dan asam amino pada domain pengikatan ligan RE $\alpha$ berjarak lebih dari 5,0 $\AA$, maka interaksi tersebut lemah pada sistem RE $\alpha$ - ligan. Gugus yang bersifat nonpolar pada estrogen juga berperan interaksinya dengan asam amino pada domain pengikatan ligan RE $\alpha$.

Gugus hidroksi fenolik pada C-15 membentuk ikatan hidrogen dengan $\mathrm{Thr}$ 483 dengan panjang ikatan 2,73 $\AA$ (pada Gambar 2). Estrogen mengikat dengan energi afinitas yang paling negatif karena mempunyai konformasi ligan stabil yang berinteraksi kuat dengan tiga asam amino bersifat nonpolar. 


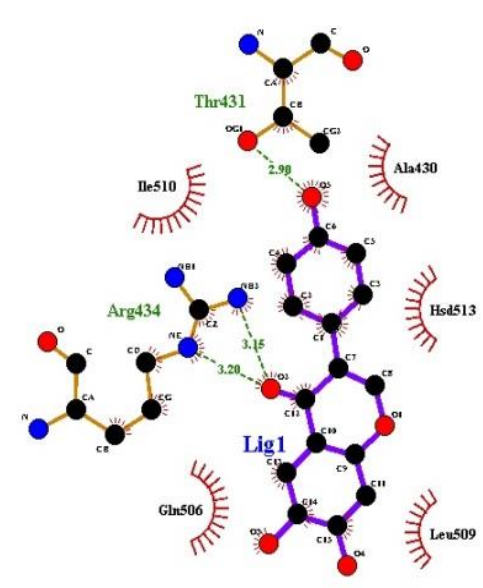

Gambar 3. Hasil Ligplot Interaksi RE $\alpha$ dengan Faktor II.

Dari hasil pengamatan interaksi antara RE $\alpha$ dengan faktor II (Gambar 3) merupakan interaksi dengan tiga ikatan hidrogen yaitu interaksi antara gugus hidroksi fenolik pada atom C4' dengan Thr 431 Gugus fungsi yang berperan pada interaksi antara Reseptor Estrogen $\alpha$ dengan faktor II adalah gugus fenolik C4' berinteraksi kuat asam amino polar yaitu dengan Thr 431. Adanya dua ikatan hidrogen ini membuat stabil sehingga energi afinitasnya sangat rendah. Gugus hidroksi fenolik C6 berinteraksi dengan asam amino yang bermuatan positif Arg 434.

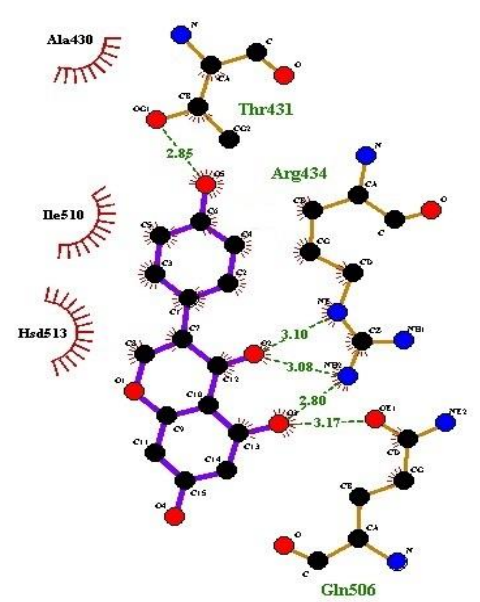

Gambar 4. Hasil Ligplot Interaksi RE $\alpha$ dengan Genistein
Dari hasil pengamatan interaksi antara RE $\alpha$ dengan genistein (Gambar 4) merupakan interaksi dengan lima ikatan hidrogen yaitu interaksi antara gugus hidroksi fenolik pada atom C6 dengan Thr 431 dengan panjang ikatan 2,85 , gugus hidroksi fenolik pada atom $\mathrm{C} 12$ membentuk ikatan hidrogen dengan Arg 434 pada dua atom nitrogen yang berbeda dengan panjang ikatan $3,10 \AA$ dan $3,08 \AA$ dan gugus fenolik pada atom C13 yang membentuk ikatan hidrogen dengan Arg 434 dan Gln 506. Adanya lima ikatan hidrogen ini membuat stabil sehingga energi afinitasnya sangat rendah.

\section{KESIMPULAN DAN SARAN}

Isoflavon yang terdapat pada tempe terutama faktor II mempunyai potensi yang paling baik sebagai hormon pengganti estrogen karena mempunyai energi afinitas yang paling tinggi diantara isoflavon lain terhadap $\mathrm{RE} \alpha$ dengan potensi estrogenik $94,52 \%$.

Perlu dilakukan penelitian pada skala laboratorium, peran faktor II sebagai pengganti hormon estrogen pada reseptor estrogen $\alpha$.

\section{DAFTAR RUJUKAN}

Allred, Craig, D., Brown, P., \& Medina, D. (2004). The origin of estrogen receptor alpha-positive and estrogen alpha-negative human breast cancer. Texas, USA. Breast Cancer Research, 6, 240-245.

Clark, J.H, Schrader, W.T, \& O’Malley, B.W. (1992). Mechanisms of action of Steroid hormones. In : Wilson J, Foster DW (eds) Textbook of Endocrinology. WB Saunders Company, Philadelphia, 35-90. 
Gyorgy, P., Murata, K., \& Ikehata, H. (1964). Antioxidants isolated from fermented soybeans tempeh. Nature. $203,872-875$.

Kuiper, \& George G. J. M. (1998). ENDOCRINOLOGY: Interaction of estrogenic chemicals and phytoestrogens with estrogen receptor $\beta$. The Endocrine Society. 139, 4252-4263.

Prawiroharsono, S. (2001). Prospek dan Manfaat isoflavon untuk kesehatan. http://www.tempo.co.id/medika/arsip /042001/pus-s.htm.

Trott O., \& Olson A. (2010). Autodock Vina: Improving the speed and accuracy of docking with $\mathrm{s}$ new scoring function, efficient optimization and multithreading. $J$ Comp Chem, 31, 455-461. 